\title{
Pemodelan Karaketeristik Papan Tanda Informasi untuk Ruang Usaha Pengrajin Batik Plentong di Yogyakarta
}

\author{
Ratih Pertiwi dan Waslam \\ Desain Komunikasi Visual, Fakultas Desain dan Industri Kreatif, Universitas Esa Unggul Jakarta \\ e-mail: ratih.pertiwi@esaunggul.ac.id
}

\begin{abstract}
Abstrak - Batik Plentong yang berada di Daerah Istimewa Yogyakarta didirikan pada tahun 1952. Fenomena permasalahan dalam penelitian ini adalah untuk memberikan gambaran mengenai pemodelan papan tanda informasi yang terdapat di ruang usaha pengrajin Batik Plentong belum memiliki karakteristik sesuai dengan standarisasi. Terdiri dari penggunaan huruf, penggunaan simbol, penggunaan warna dan pemilihan material. Dalam menghadapi Making Indonesia 4.0 erat kaitannya dengan revolusi industri, maka papan tanda informasi disetiap bidang usaha diperlukan sebagai penunjang atas keberhasilan dari suatu kegiatan industri guna meningkatkan jumlah pengunjung. Metode penelitian ini menggunakan metode penelitian kualitatif, melalui pendekatan fenomenologi.. Penulis menggunakan pendekatan fenomenologi yang melibatkan semua panca indera dalam melakukan pengamatan terhadap objek penelitian. Kebaruan yang dihasilkan adalah pemilihan dan penggunaan material yang ramah lingkungan dan tahan terhadap reaksi kimia, dengan alasan kondisi lokasi dari sebuah proses pembatikan yang erat kaitannya dengan bahan malam dan bahan kimia. Selain itu, kebaruan lainnya yang peneliti lakukan adalah penggunaan aspek elemen grafis. Seperti menambahkan dan memberikan simbol (ikon) di masing-masing dari proses pembatikan untuk ruang usaha pengrajin Batik Plentong. Kesimpulan yang diperoleh adalah perlu adanya sebuah karakteristik dari pemodelan papan tanda informasi sebagai bagian dari suatu proses kegiatan yang dapat digunakan oleh publik umum.
\end{abstract}

Kata kunci: pemodelan, karakteritik, dan papan tanda informasi.

\begin{abstract}
Plentong Batik in Yogyakarta Special Region was established in 1952. The phenomenon of the problem in this study is to provide an overview of information sign board modeling in the business space of Batik Plentong craftsmen who do not have the characteristics according to standardization.Consists of the use of letters, use of symbols, use of colors and material selection.In dealing with Making Indonesia 4.0 is closely related to the industrial revolution, the information sign board in each business field is needed as a support for the success of an industrial activity in order to increase the number of visitors.This research method uses qualitative research methods, through a phenomenological approach.The author uses a phenomenological approach that involves all five senses in observing the object of research.The novelty produced is the selection and use of materials that are environmentally friendly and resistant to chemical reactions, with the reason that the location conditions of a batik process are closely related to night matter and chemicals. In addition, another novelty that researchers do is the use of graphic elements.Like adding and giving symbols in each of the batik processes for the business space of Batik Plentong craftsmen.The conclusion obtained is
\end{abstract}

that there needs to be a characteristic of information sign board modeling as part of an activity process that can be used by the general public.

Keywords: modeling, characteristics, and information sign board.

\section{PENDAHULUAN}

Perusahaan kain batik Plentong terletak di jalan Tirtodipuran No. 48 kotamadya Yogyakarta, juga untuk melestarikan seni batik tulis dan batik cap sekaligus berwirasasta. Papan tanda informasi atau sering dikenal dengan kata information signage board adalah sejenis visual graphic dalam ukuran besar yang dibuat untuk menyampaikan informasi pada kalangan audience tertentu. Belum memiliki environmental graphic di perusahaan kain batik plentong juga menjadi salah satu temuan yang akan dilakukan terkait dari segi bentuk dan sistem grafis lingkungannya.

Papan tanda informasi dapat dikelompokan berdasarkan karakteristik media, menurut konsumsi media berdasarkan waktu, yaitu map sign (dilihat dari dekat dalam waktu yang lama), signage lokasi (dilihat dari dekat dalam waktu yang cepat), signage arah (dilihat dari jauh dalam waktu yang cepat), dan signage fasilitas umum (dilihat dari jauh dalam waktu yang cepat) [1]. Ruang lingkup dalam penelitian ini adalah desain papan tanda informasi yang memiliki unsur kenyamanan, efisiensi, penentuan dan pemilihan juga berperan dari segi kualitas dan keunggulan, penggunaan tipografi. Dalam penelitian ini hanya dibatasi oleh ruang lingkup kenyamanan dan kemudahan dalam menyampaikan informasi ke media papan tanda informasi yang memiliki karakteristik dari sebuah proses pembatikan. Untuk mewujudkan suatu tampilan visual, ada beberapa unsur yang diperlukan, antara lain :

a. Titik (salah satu unsur visual yang wujudnya relatif kecil, di mana dimensi memanjang dan melebarnya dianggap tidak berarti).

b. Garis (unsur visual yang banyak berpengaruh terhadap pembentukan suatu objek sehingga garis, selain dikenal sebagai goresan atau coretan juga menjadi batas suatu bidang atau warna.

c. Bentuk (seperangkat garis yang ditempatkan berdekatan, memiliki diameter, tinggi dan lebar. Ini merupakan objek dua dimensi. Berdasarkan sifatnya, bentuk dapat dikategorikan menjadi tiga, yaitu huruf, simbol dan bentuk nyata (form). Selain itu hal ini dapat digunakan sebagai perantara sebuah ide).

d. Ruang (ruang dapat dihadirkan dengan adanya bidang. Pembagian bidang atau jarak antara objek berunsur titik, garis, bidang dan warna).

e. Warna (sebagai unsur visual yang berkaitan dengan bahan yang mendukung keberadaannya ditentukan oleh jenis pigmennya).

f. Tekstur (sebuah visualisasi dari permukaan yang dapat dinilai dengan cara dilihat atau diraba. Secara fisik tekstur dibagi 
menjadi tekstur kasar dan halus dan dengan kesan pantul mengkilat atau kusam).

g. Ukuran (seberapa besar atau kecil sesuatu hal. Perbandingan ukuran satu bentuk terhadap bentuk lainnya. Dengan menggunakan elemen ini, dapat, menciptakan kontras dan penekan (emphasis) pada objek desain) [2].

Adapun kajian riset sebelumnya menitik beratkan pada penelitian 'Perancangan Signage Revitalisasi Terminal Purabaya' oleh Galih Aryo Yudistiawan. Menjelaskan bahwa signage selama ini dikenal dan digunakan untuk mengidentifikasi, mengarahkan dan menginfromasikan.Tapi saat ini muncul kebutuhan yang lebih luas daripada sebelumnya bagi signage untuk mengidentifikasikan sebuah area.Area-area tersebut dapat berupa sebuah situs proyek, bagian tertentu dari sebuah jalan yang berbelok-belok menuju suatu tempat tertentu yang didalamnya mempunyai fungsi dan tujuan, sehingga para pengguna fasilitas umum akan lebih merasakan kenyamanan.

Pada penelitian sebelumnya oleh Aniendya Christianna dengan judul penelitian'Desain Signage sebagai Solusi Pencemaran Visual' Menjelaskan bahwa reperesentasi budaya bangsa dapat diidentifikasi melalui aspek estetika lingkungan. Salah satu unsur utama lingkungan, pada khususnya desain perkotaan, yakni papan petunjuk informasi (signage).Dimana signage adalah bentuk komunikasi yang kini sangat dibutuhkan sebagai suatu sarana informasi.Dikarenakan terdapat fungsi-fungsi penting signage yang telah terabaikan.

Kebaruan yang dihasilkan adalah pemilihan dan penggunaan material yang ramah lingkungan dan tahan terhadap reaksi kimia, dengan alasan kondisi lokasi dari sebuah proses pembatikan yang erat kaitannya dengan bahan malam dan bahan kimia. Permasalahan dalam penelitian ini adalah bagaimana menentukan pemodelan papan tanda informasi sesuai karakteristik berdasarkan aspek material dan elemen desain grafis? Bagaimana proses dari pemodelan papan tanda informasi untuk ruang usaha pengrajin Batik Plentong Yogyakarta?

Tujuan fungsional dari penelitian ini yang akan di analisa adalah dapat diketahui jenis bahan material yang baik dan pemodelan dari rambu-rambu di dalam bangunan gedung, seperti peletakan, penentuan dimensi, penggunaan huruf, penggunaan simbol dan penggunaan warna sehingga, dapat dipastikan parameter kenyamanan dan kemudahan bagi wisatawan dalam menerima informasi petunjuk arah. Dengan demikian diharapkan dari penelitian ini, model karakteristik sebagai acuan dalam merancang sebuah desain papan tanda informasi.

Selain itu, adapun tujuan individual dari suatu penelitian yaitu melakukan penelitian guna menambah ilmu pengetahuan, pengenalan, pengalaman dan pemahaman terhadap suatu fakta atau informasi yang terjadi di masyarakat. Peneliti dapat memperoleh penghargaan dari hasil penelitian ketika dapat menemukan pengalaman baru. Hal itu merupakan salah satu manfaat penelitian bagi peneliti. Pengetahuan baru juga dapat bermanfaat bagi masyarakat luas ketika dapat menyelesaikan suatu masalah. Sehingga penemuan terhadap hal baru dapat memberikan manfaat bagi peneliti maupun masyarakat.

\section{METODE}

Penulis menerapkan penggunaan metode kualitatif fenomenologi yang berlandaskan pada kebenaran empirik sensual, logika, etika dan atas dasar kebenaran ini fenomenologi menghendaki kesatuan antara subyek peneliti dengan pendukung objek penelitian [3]. Keterlibatan subjek peneliti di lapangan dan penghayatan fenomena yang dialami menjadi salah satu ciri utama.Penelitian kualitatif sangat dipengaruhi oleh pandangan, pemikiran dan pengetahuan peneliti karena data tersebut diiterpretasikan oleh peneliti. Oleh karena pada penelitian ini, penulis menggunakan pendekatan fenomenologi yang melibatkan semua panca indera dalam melakukan pengamatan terhadap objek penelitian. Untuk itu penulis akan menceritakan pengalaman yang penulis alami selama meneliti papan tanda informasi bagi perusahaan batik Plentong di Yogyakarta. Penulis atau peneliti mencoba untuk menelusuri jejak-jejak informasi mengenai papan tanda informasi dan untuk memahami, mendalami, mengidentifikasi, melihat hubungan dan mengangkat sejumlah masalah.

\section{HASIL DAN PEMBAHASAN}

Berdasarkan wawancara mendalam, survey Batik Plentong Yogyakarta (Gambar 1), dan diskusi dengan anggota maka ditentukan sebuah hasil penelitian, berikut ini akan diuraikan dari aspek elemen desain grafis dan aspek material. Dalam tinjauan elemen desain komunikasi visual dari aspek grafis yang terbentuk dari papan tanda informasi yang terdapat pada signage Batik Plentong. Desain Komunikasi Visual dapat dikatakan sebagai seni menyampaikan pesan dengan bahasa rupa yang disamapikan melalui media papan tanda informasi berupa desain yang bertujuan menginformasikan, mempengaruhi hingga mengubah perilaku pengunjung sesuai dengan tujuan yang diinginkan.

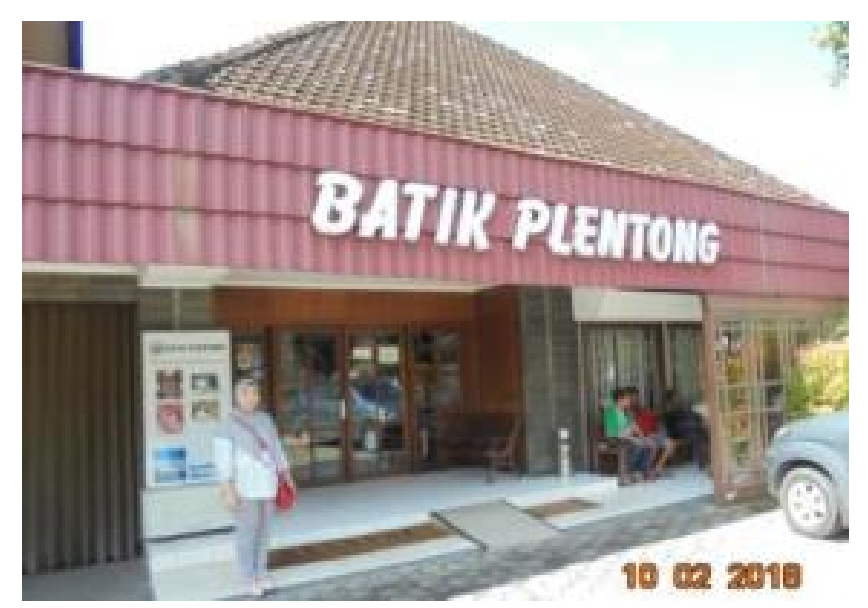

Gambar 1. Batik Plentong Yogyakarta.

Isi pesan diungkapkan secara kreatif dan komunikatif serta mengandung solusi untuk permasalahan yang akan disampaikan. Berikut ini diuraikan elemen-elemen dalam desain grafis ;

\section{Ukuran Media}

Dalam desain grafis yang paling utama adalah ukuran media. Penting untuk menentukan komposisi dan tata letak dalam suatu desain. Papan tanda informasi yang telah dibentuk sebelumnya oleh pemiliki Batik Plentong dengan ukuran lebar $43 \mathrm{~cm} \times$ tinggi $13,5 \mathrm{~cm}$

2. Titik

Dalam aplikasi pemodelan pada papan tanda informasi terdiri dari proses membatik, tidak ditemukan adanya titik.

3. Garis

Garis terdiri dari unsur titik yang memiliki peran untuk mendukung keindahan, keseimbangan dan harmoni. Hal ini terlihat pada garis tebal yang mengelilingi media papan tanda informasi, memberikan makna tegas. Selain itu, terdapat garis melengkung pada empat sisi segi empat yang berarti dinamis.

4. Bentuk

Bentuk atau shape juga diartikan form, terutama berkaitan dengan benda-benda dua dimensi. Papan tanda informasi yang terdapat pada ruang usaha batik plentong berbentuk rectangle atau segi empat atau persegi empat. Bentuk ini disebut dengan geometris Makna dari segi empat adalah fisik, masyarakat, kesederhanaan, dan aksi.

5. Tekstur

Tekstur menyangkut sifat dan kualitas fisik permukaan suatu benda, seperti kusam, mengkilap, kasar, halus dapat diaplikasikan dalam desain. Pada papan tanda informasi batik Plentong memiliki 
dua tekstur yakni tekstur halus dan tekstur kasar. tekstur kasar pada keterangan huruf dikarenakan menggunakan teknik emboss sehingga menciptakan tekstur timbul pada permukaan yang halus. Sedangkan tekstur halus berada diantara garis lurus dan tipografi (kata/huruf).

\section{Ruang atau space kosong}

Ruang terkait dengan kedalaman sehingga memberikan kesan jauh dekat, tinggi dan rendah dan untuk mengarahkan kepada objek desain. Adanya ruang antara garis dan huruf memberikan komposisi kata/huruf berada ditengah media papan tanda informasi.

\section{Tipografi}

Merupakan seni memilih dan menata huruf pada ruang untuk menciptakan kesan khusus. Penggunaan dan pemilihan huruf yang digunakan pada papan tanda informasi adalah huruf yang umumnya digunakan pada aplikasi plat nomor kendaraan. Pada dasarnya plat nomor kendaraan telah memiliki standarisasi tertentu. 8. Warna

Tingkatan warna yang digunakan dapat menentukan kesan yang ditampilkan. Papan tanda informasi pada batik plentong, menggunakan dua warna yaitu warna hitam dan putih.

Dibawah ini terdapat beberapa aspek yang berkaitan karakteristik papan tanda informasi.

\section{Aspek material}

Tanda informasi memiliki beberapa pilihan material, antara lain dengan bahan akrilik, plat logam (seng dan besi) dan kayu. Akan tetapi dari ketiga material tersebut tentunya terdapat kelebihan dan kekurangan masing-masing [4]. Sehingga peneliti menentukan pilihan material pada bahan akrilik dan plat logam. Pilihan material pertama adalah material akrilik. Adapun keunggulan dari material akrilik adalah tidak bereaksi pada sinar matahari, tahan terhadap cuaca luar area, dapat didaur ulang atau ramah lingkungan, tahan pada reaksi kimia, kejernihan akrilik dapat bertahan hingga bertahun-tahun. Akrilik yang digunakan adalah jenis akrilik ekstrusi, lembaran akrilik ini lebih lembut dibandingkan akrilik cetakan.

Akrilik jenis ini merupakan pilihan yang paling baik nuntuk membuat plang, display dan lainnya. Kemudian pemilihan material kedua adalah material plat logam. Yang dimaksud adalah material plat nomor kendaraan roda empat. Pada material plat ini sebelumnya telah digunakan selama bertahun-tahun oleh Batik Plentong. Berdasarkan hasil wawancara dengan pemilik Batik Plentong, alasan penggunaan material plat kendaraan untuk papan tanda informasi di ruang usaha pembatikan dikarenakan keawetan dari kualitas material tersebut. Penggunaan material plat kendaraan pada papan tanda informasi dimaksudkan juga ingin menjaga identitas ciri khas papan penanda yang menggunakan material yang sama di jalan-jalan protokol kota Yogyakarta (Gambar 2).

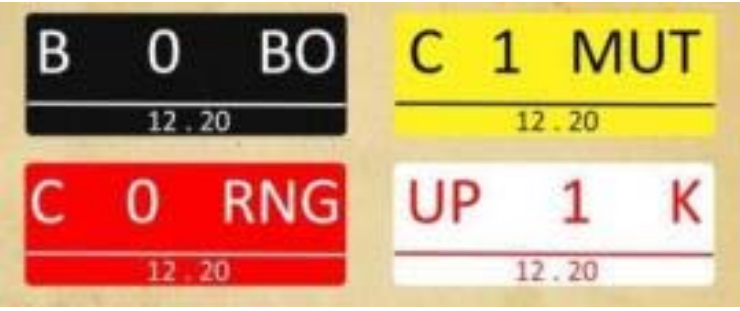

Gambar 2. Jenis warna plat nomor kendaraan,

http://banjarmasin.tribunnews.com/2018/03/08/arti-warna-pelat-nomorkendaraan-di-indonesia-jenis-ini-jarang-ditemui?page $=3$, di unduh 15 agustus 2018, 12:56 wib

Aspek Grafis (tipografi, warna dan bentuk transformasi motif kawung)

Berawal dari bentuk transformasi motif kawung, penulis akan menguraikan terkait filosofi batik kawung. Salah satu alasan penggunaan dan pemilihan motif kawung sebagai simbol adalah batik kawung merupakan motif tertua yang pernah ada yaitu dari abad ke-9. Berbentuk seperti kolang-kaling disusun pada empat sudut persegi [5]. Makna batik kawung diantaranya adalah pengendalian diri yang sempurna, hati yang bersih tanpa adanya keinginan untuk berfoya. Nama dan motif kawung dilansir berasal dari dua sumber. Yang pertama adalah serangga Kwangwung dan yang kedua adalah buah kolang-kaling.

Seiring perkembangan zaman, setelah Kerajaan Mataram dibagi menjadi dua, Surakarta dan Yogyakarta. Batik Kawung mulai digunakan oleh golongan-golongan yang berbeda-beda. Batik kawung bahkan identik dengan Tokoh Punakawan yang paling terkenal, Semar. Dalam pewayangan, semar sering terlihat menggunakan batik bermotif kawung. Sosok semar berasal dari kalangan rakyat biasa, namun senantiasa mengabdi pada Pandawa dan menjadi simbol kebijaksanaan. Karakter Semar yang terasa sangat dekat dengan masyarakat umum turut menyebarkan popularitas dari motif batik Kawung kepada khalayak ramai.

Gambar 3 menjelaskan bentuk geometri yang terdapat pada batik berupa titik, garis dan bidang datar. Bidang datar tersebut misalnya lingkaran, elips, segiempat dan sebagainya. Bentukan artistik pada batik dihasilkan melalui transformasi titik, garis atau bidang datar tersebut melalui translasi (pergeseran), rotasi (perputaran), refleksi (penceminan) atau dilatasi (perkalian) [6].
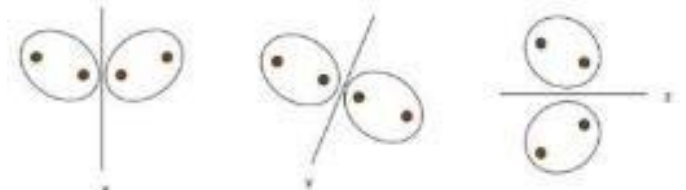

Gambar 3. Bentukan pada motif batik Kawung, https://wendiferdintania.wordpress.com/2014/12/17/geometritransformasi-dalam-karya-seni-batik-di-indonesia/, diunduh 20 agustus 2018, 18:11 wib

Bentukan pada motif batik kawung dapat dipandang sebagai hasil refleksi (pencerminan) bentuk dasar. Hasil pencerminan Gambar 1 pada garis $\mathrm{x}$, y, dan $\mathrm{z}$ menghasilkan orientasi bentuk sebagai berikut (Gambar 2, Gambar 3 dan Gambar 4). Hal ini penulis terapkan seperti pada Gambar 4. Bentuk dasarnya adalah elips dan titik. Berdasarkan transformasi yang dihasilkan dari motif kawung, maka pemodelan pada papan tanda informasi membentuk geometris yang lebih disederhanakan menjadi bentuk elips.

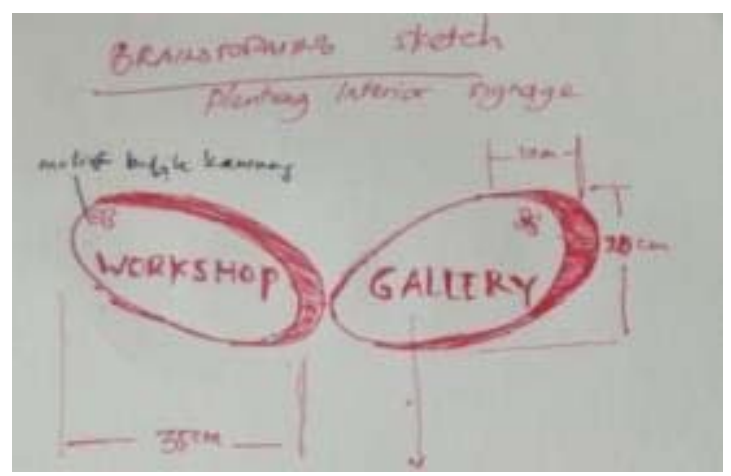

Gambar 4. Sketsa kasar pemodelan alternatif kedua.

Selain analisa mengenai bentuk, kemudian penulis menentukan dan memilih warna yang sesuai dengan filosofi warna. Seperti yang terdapat pada Gambar 5, bahwasanya penulis menggunakan warna antara lain warna merah, warna kuning, dan warna hijau. Sebagai uraiannya, warna merah digunakan dan diartikan pada area yang tidak diperkenankan bagi pengunjung untuk mendekati area tersebut, antara lain Proses Pencelupan warna indigosol, pencelupan warna nepthol, dan proses penjemuran (nglorod). Warna kuning digunakan pada area proses membatik, pengecapan, dan pewarna coletan. Hal ini dilakukan yang berarti, pengunjung diperbolehkan mendekat dengan proses tersebut dan bagi 
pengunjung yang ingin mempelajari menggunakan canting dan lilin di khususkan bagi kelas kursus. Namun lain halnya pada proses memola diberikan warna hijau pada simbol tersebut. Yang memiliki makna, bahwa dalam penggunaan warna rambu lalulintas warna hijau adalah diperbolehkan jalan.

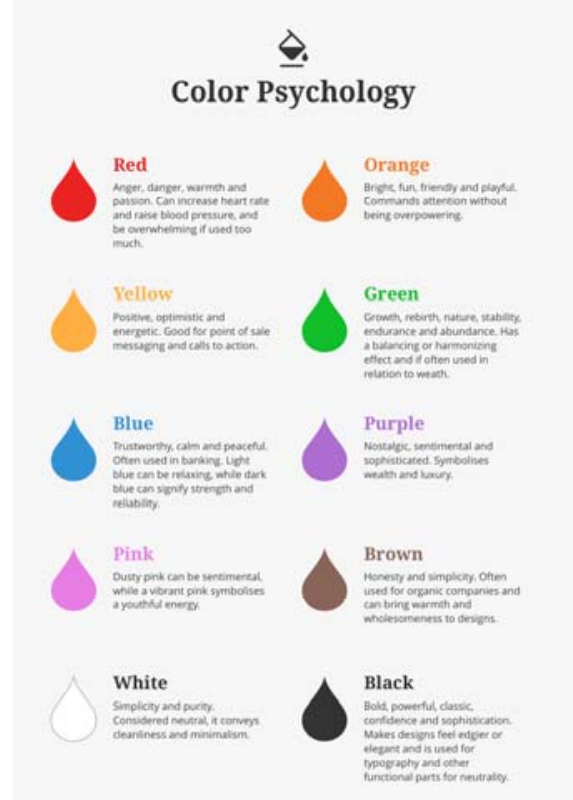

Gambar 5. Psikologi Warna, https://convertkit.com/color-theory-for-bloggers/, diunduh 15 agustus 2018, 11. 54 wib

Dalam pemodelan papan tanda informasi terdapat beberapa elemen desain grafis. Tipografi menjadi salah satu dari elemen desain grafis tersebut. Tipografi merupakan hal penting dalam penjelasan dari isi pesan yang akan disampaikan. Langkah awal untuk mempelajari tipografi adalah memahami anatomi huruf secara seksama. Seperti halnya tubuh manusia, huruf memiliki berbagai organ yang berbeda. Gabungan seluruh elemen dari sebuah bentuk huruf merupakan identitas visual yang dapat membedakan antara huruf yang satu dengan huruf yang lain.

Hasil Pemodelan Information Signage Board atau Papan Tanda Informasi adalah Dalam penelitian ini, diperlukan pemilihan untuk menentukan bahan material sebagai bagian dari proses pemodelan. Maka ditentukan material akrilik, dengan alasan tidak bereaksi terhadap sinar matahari dan tahan pada cuaca luar area melihat kondisi ruang usaha di Batik Plentong yakni menggunakan bantuan kipas angin dan pelindung atap (semi ruang terbuka). Keunggulan lainnya menggunakan material akrilik adalah dapat di daur ulang dan mudah dibersihkan, hal ini mempermudah dari aspek perawatan papan tanda informasi. Selain berfungsi penunjuk arah dan informasi, papan tanda informasi juga dapat dikatakan sebagai fasilitas publik bagi pengguna ruang usaha Batik Plentong (pengunjung atau tamu).

Pada ruang usaha Batik Plentong atau workshop terdapat campur tangan dari proses reaksi kimia, seperti proses membatik dengan canting dan bahan lilin, proses cap dengan penggunaan kompor, dan proses nglorod dimana dalam prosesnya menggunakan teknik pencelupan dengan bahan kimia yang disebut pencelupan napthol dan pencelupan indigosol. Sehingga pemilihan material akrilik yang akan digunakan untuk papan tanda informasi menjadi sesuai, dengan keunggulan tahan pada reaksi kimia, ramah lingkungan dan tidak mengandung racun.

Telah diuraikan mengenai alasan dari menggunakan bahan material. Proses selanjutnya adalah pemodelan, dengan dilakukan dua pemodelan sebagai alternatif. Berdasarkan data yang diperoleh, proses pemodelan alternatif pertama papan tanda informasi untuk ruang usaha Batik Plentong antara lain, sebagai berikut ;

Langkah pertama membuat konsep perancangan melalui sketsa kasar. Ditentukan dua bentuk alternatif, yaitu bentuk kotak dan bentuk elips (merepresentasikan motif batik kawung).
Langkah kedua, dari aspek elemen desain grafis bentuk pemodelan alternatif pertama kotak dengan diberi pewarnaan hitam pada akrilik dengan tujuan merepresentasikan dari desain plat nomor kendaraan. Melalui pendekatan fenomenologi, setelah dilakukan wawancara mendalam dengan pemilik Batik Plentong (Ibu Sri Widayati Laksmi) menjelaskan alasan menggunakan bahan material plat kendaraan untuk papan tanda informasi di ruang usaha Batik Plentong adalah awet dan mempertahankan kesan kuno, nostalgia, dan tradisional.

Langkah ketiga, untuk pemodelan pertama (bentuk kotak) menggunakan material akrilik dengan ketebalan $2 \mathrm{~mm}$, dan panjang $\times$ lebar $=244 \times 120 \mathrm{~cm}$ dengan menggunakan akrilik warna bening dan warna putih susu pada huruf (teknik cutting laser).

Langkah keempat, akrilik dipotong menjadi dua lembar dengan masing-masing ukuran lembar untuk sisi belakang $49 \mathrm{~cm} \times 17,5$ $\mathrm{cm}$ dan lembar sisi depan (diberikan cat warna hitam untuk keseluruhan lembar akrilik) $43 \mathrm{~cm}$ x 13,5 cm.

Langkah kelima, pada lembar akrilik sisi depan akan ditempel (menggunakan lem) huruf sesuai keterangan informasi proses membatik, simbol motif kawung dan simbol dari informasi tersebut. Pada prosesnya, menggunakan teknik cutting laser untuk membentuk huruf dan simbol.

Langkah keenam, di bagian lembar akrilik sisi depan dan belakang dilakukan pengeboran guna dipasang empat baut untuk ditempel pada dinding tembok. Tahapan di atas dapat dilihat pada Gambar 6, proses cutting laser

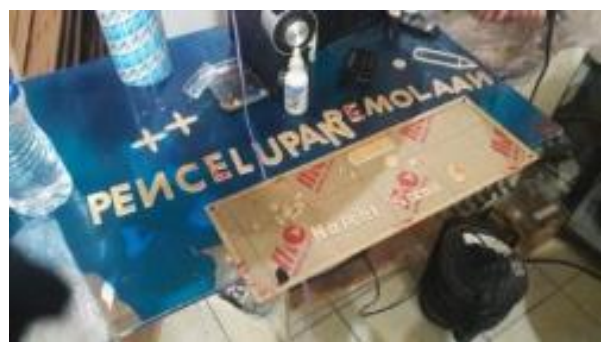

Gambar 6. Proses cutting laser.

Selanjutnya pada Gambar 7, diuraikan mengenai pemodelan alternatif pertama. Yang terdiri antara lain, penggunaan material, ukuran yang diterapkan pada media akrilik, dan teknik aplikasi menggunakan cutting laser.

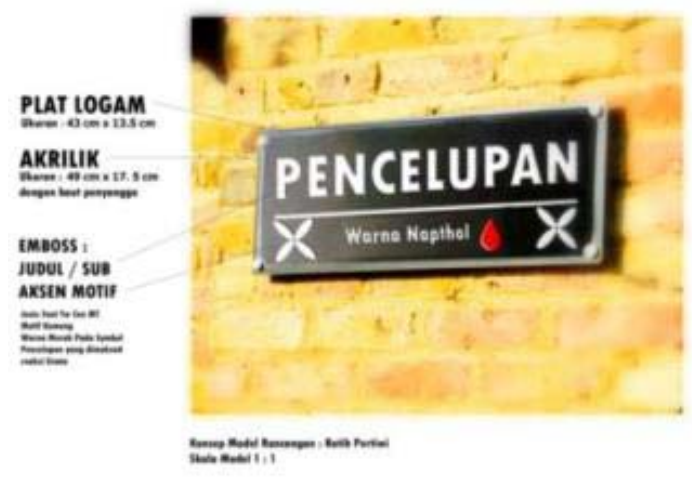

Gambar 7. Pemodelan alternatif pertama.

Gambar 8 menunjukkan hasil akhir dari pemodelan untuk alternatif pertama. Langkah berikutnya untuk pemodelan alternatif kedua, yaitu menggunakan akrilik dengan ketebalan $2 \mathrm{~mm}$ yang berukuran $50 \mathrm{~cm} \times 32 \mathrm{~cm}$. Perbedaannya dengan pemodelan alternatif pertama, untuk pemodelan alternatif kedua akrilik yang digunakan hanya satu lembar dan warna disesuaikan zona aman, hati-hati dan dalam pengawasan hal ini diambil berdasarkan proses pembatikan yang terdapat di Batik Plentong Yogyakarta. Diuraikan langkah dari proses pemodelan sebagai berikut: 
Langkah pertama, lembaran akrilik dipotong base atau dasar sesuai dengan ukuran yang telah ditentukan. Langkah kedua, dilakukan tahapan cutting terutama pada bagian simbol dan huruf sesuai dengan desain yang telah ditentukan.

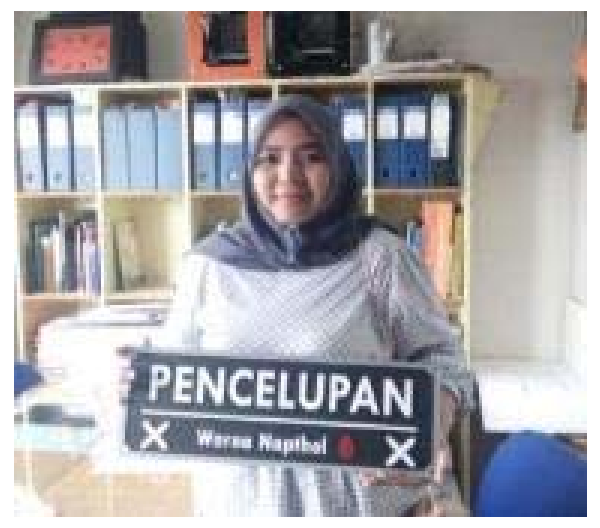

Gambar 8. Hasil akhir pemodelan alternatif pertama.

Langkah ketiga, dilakukan pengeboran dua sisi untuk hasil akhir lubang yang diberikan rantai sebagai fungsi dipasang pada langitlangit atap ruang usaha Batik Plentong. Hal ini dapat dilihat dari keterangan pada Gambar 9, terkait mind mapping dari pemodelan untuk alternatif kedua.

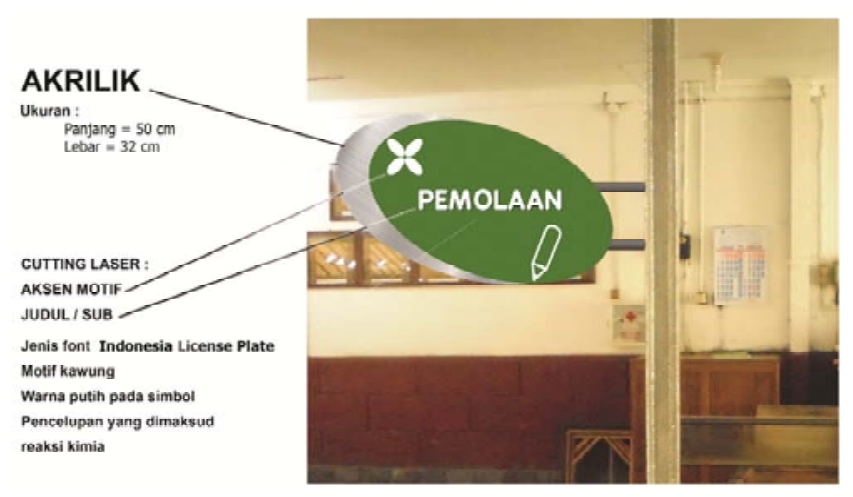

Gambar 9, Pemodelan alternatif kedua.

Selanjutnya berdasarkan Gambar 10, diuraikan mengenai pemodelan alternatif kedua. Yang terdiri antara lain, penggunaan material, ukuran yang diterapkan pada media akrilik, dan teknik aplikasi menggunakan cutting laser. Selain itu, merupakan hasil akhir dari pemodelan untuk alternatif kedua.

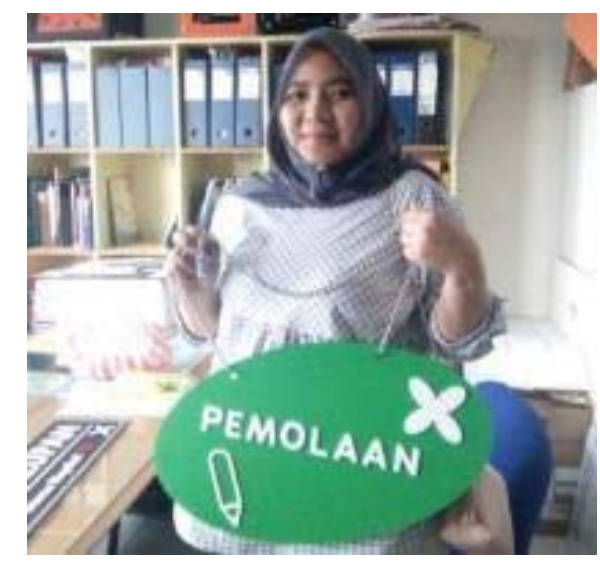

Gambar 10. Hasil akhir pemodelan alternatif kedua.

\section{KESIMPULAN/RINGKASAN}

Berdasarkan ruang lingkup yang dibahas adalah kenyamanan dan kemudahan dalam menyampaikan informasi ke media papan tanda informasi yang memiliki karakteristik dari sebuah proses pembatikan maka dapat disimpulkan bahwa diperlukan beberapa tahapan dalam proses pemodelan dimulai dari pemilihan material, menentukan desain kemudian membuat sketsa kasar, dilanjutkan menentukan dan mendesain untuk huruf serta simbol dikuti dengan memilih warna yang akan diaplikasikan pada objek penelitian. Kemudian pemodelan bentuk mulai dilakukan pengerjaan tiga dimensi 1 : 1 . Diawali dengan pemilihan material akrilik, menentukan ukuran pada objek, dilakukan proses laser cutting untuk pembuatan huruf dan simbol, dan dilanjutkan ke proses aplikasi pemodelan melalui penempelan huruf dan simbol pada papan dasar akrilik.

\section{UCAPAN TERIMA KASIH}

Pelaksanaan Penelitian Dosen Pemula untuk Tahun Anggaran 2018 ini tidak terlepas dari kerjasama dan bantuan dari berbagai pihak, oleh karena itu penghargaan dan terima kasih setulusnya Tim Peneliti haturkan kepada :

1. Direktur Riset dan Pengabdian Masyarakat, Kementerian Riset, Teknologi, dan pendidikan Tinggi, yang telah memberikan kepercayaan Tugas dan Biaya kepada Tim Peneliti untuk melakukan Penelitian Dosen Pemula. .

2. Ibu pemilik dari Batik Plentong Yogyakarta, selaku Narasumber utama yang telah menyediakan waktu untuk wawancara secara langsung dan memperkenankan berkunjung ke ruang usaha pengrajin Batik Plentong.

\section{DAFTAR PUSTAKA}

[1] Bungin, Burhan. Penelitian Kualitatif. Edisi kedua. Jakarta: Kencana. 2011

[2] Endaswara, Suwardi. Metode, Teori, Teknik Penelitian Kebudayaan. Pustaka Widyatama. 2006.

[3] Moleong, Lexi J..Metodologi Penelitian Kualitatif. Bandung: Remaja Rosda Karya. 2000.

[4] Palgudani, Bram. Desain Produk 2, Analisis dan Konsep Desain. Bandung: Penerbit ITB. 2008.

[5] Sachari, Agus. Estetika - Makna, Simbol dan Daya. Cetakan ke 3. Bandung: Penerbit ITB. 2006.

[6] Sign of Cafe and Restaurant, London (UK) : Design Media Publishing. ISBN : 979-11-955459-4-0 